\author{
Sustinere \\ Journal of Environment and Sustainability \\ Volume 4 Issue 1 (2020) 33-42 \\ Print ISSN: 2549-1245 Online ISSN: 2549-1253 \\ Website: https://sustinerejes.com E-mail: sustinere.jes@iain-surakarta.ac.id
}

\title{
RESEARCH PAPER \\ Efficiency of multi soil layering (MSL) system in a household scale of wastewater treatment using environmental friendly materials
}

\author{
Badrus Zaman *, Wiharyanto Oktiawan \\ Dept. of Environmental Engineering, Faculty of Engineering, Diponegoro University, Indonesia \\ Article history: \\ Received 26 April 2020 | Accepted 20 May 2020 | Available online 29 May 2020
}

\begin{abstract}
Most community settlements in Indonesia do not have a household scale of a wastewater treatment plant. Fatal impacts on the environment and human health can occur at any time, including causing environmental damage (disaster), damaging beauty/aesthetics for the scenery will be unpleasant and foul-smelling, polluting water bodies, and endangering health. The purpose of this study is to optimize the Multi Soil Layering (MSL) System to treat domestic wastewater (greywater) using environmentally friendly materials that are available in Indonesia. The research method used the MSL system with the first variation using a batch system with Hydraulic retention time (HRT) for 24 hours and the second variation using an intermittent system with 3, 6, 9 hours HRT. The results showed that the MSL system was able to eliminate COD well. The highest COD removal efficiency was $93.44 \%$ at 9 hours HRT, but the effluent quality did not meet the required quality standards. The development of MSL systems that produces an effluent quality that meets the quality standards needs to be studied further
\end{abstract}

Keywords: Multi Soil Layering; COD; domestic waste

\section{Introduction}

Most community settlements in Indonesia do not have a household scale of a wastewater treatment plant. Liquid waste is channeled directly into water bodies (such as sewers) without any prior treatment. Fatal impacts on the environment and human health can occur at any time, including causing environmental damage (disaster), damaging beauty/aesthetics for the scenery will be unpleasant and foul-smelling, polluting water bodies, and endangering health (Santoso, 2014).

${ }^{*}$ Corresponding author. E-mail: badruszaman3214@gmail.com

https://doi.org/10.22515/sustinere.jes.v4i1.101 
Suoth and Nazir (2016) state that household wastewater (greywater) in 10 houses in one of the cities in Indonesia shows a range of pH parameter values of 6.2 - 8.5; BOD 121 - $151 \mathrm{mg} / \mathrm{L}$; TSS $121-127 \mathrm{mg} / \mathrm{L}$; COD $79-700 \mathrm{mg} / \mathrm{L}$ and fatty oils 6-9.5 mg/L. Greywater analysis results, when compared with the Ministry of Environment Regulation No. 68 of 2016 concerning Domestic Wastewater Quality Standards in some houses, exceed the quality standards. Factors causing the absence of a household scale of the wastewater treatment plant in Indonesia are the high costs and difficulties in terms of operation and maintenance. Therefore, a domestic sewage treatment system which is cheap and easy to implement, as well as providing optimal results is needed. Waste treatment methods should be applicable, relatively inexpensive, and do not require large tracts of land.

Several methods for treating domestic wastewater have been naturally applied, including lagoon, wetland, and sand filters (Latrach et al., 2018). Lagoon requires a large area and causes significant odour. Wetland is very dependent on temperature and climate (Masi \& Martinuzzi, 2007), while sand filters require more complex maintenance in operation because they are easily clogged. One method that is quite promising is Multi Soil Layering (MSL). This method has been successfully developed in Japan, Thailand, America, China, and Taiwan (Latrach et al., 2018). This method requires a relatively low cost compared to the lagoon, wetland, and sand filter. MSL requires less land, easy maintenance, not easily clogging, can be used for organic loads, has a high hydraulic loading rate, and can last up to 20 years (Chen et al., 2009).

Until now, MSL research in Indonesia is still related to hotel wastewater (Elystia et al., 2012), ethanol industry wastewater, palm oil liquid waste (Mutia et al., 2015), and paddy wastewater. Therefore, there is a need for further studies on the efficient use of the Multi Soil Layering method to treat domestic wastewater (greywater) with environmentally friendly materials that are available in Indonesia.

\section{Literature Review}

\subsection{Characteristics of Domestic Waste (Greywater)}

Regulation of the Minister of Environment and Forestry Number P.68 of 2016 concerning Domestic Wastewater Quality Standards states that domestic wastewater is wastewater that originates from human daily living activities related to water usage (MLHK-RI, 2016). The domestic waste consists of greywater and blackwater in which greywater comes from nontoilet sources such as used washing water, water from the kitchen, etc. The domestic wastewater quality standards are shown in Table 1.

Table 1. Domestic Wastewater Quality Standards

\begin{tabular}{l|c|c}
\hline \multicolumn{1}{c|}{ Parameter } & Unit & Maximum Level \\
\hline $\mathrm{pH}$ & - & $6-9$ \\
$\mathrm{BOD}$ & $\mathrm{mg} / \mathrm{L}$ & 30 \\
$\mathrm{COD}$ & $\mathrm{mg} / \mathrm{L}$ & 100 \\
$\mathrm{TSS}$ & $\mathrm{mg} / \mathrm{L}$ & 30 \\
Oil and fat & $\mathrm{mg} / \mathrm{L}$ & 5 \\
Ammonia & $\mathrm{mg} / \mathrm{L}$ & 10 \\
Total Coliform & Total/100 mL & 3000 \\
Debit & L/people/day & 100 \\
\hline
\end{tabular}

Source: Permen LHK Number P.68 of 2016 (MLHK-RI, 2016) 
The characteristics of domestic wastewater are determined by sources or human activities related to water usage, for example, bathing, cooking, washing clothes with detergent, washing vehicles, etc. Different activities will certainly produce different waste characteristics. Common parameters found in domestic wastewater include COD and ammonia parameters.

\subsection{Multi-Soil Layering (MSL) System}

Masunaga et al. (2007) mention the Multi Soil Layering method is a treatment method that utilizes the ability of the soil to treat wastewater, where the soil is arranged in a brick pattern. In this MSL method, filtration, absorption, adsorption, and decomposition mechanisms occur. The construction of the brick structure consists of a mixture of soil layers with 10-35\% iron particles, organic matter, and zeolite layers which are equipped with 2 processing zones, namely the aerobic zone in the zeolite layer and the anaerobic zone in the soil layer (Sy \& Sofyan, 2011).

According to Wakatsuki et al. (1993), the process of decomposition of organic material, phosphate fixation, nitrification, and denitrification is found in aerobic and anaerobic zones. Anaerobic layers function to form anaerobic conditions, that in the MSL system must be adjusted so that pollutants can be set aside efficiently. Organic material layers in the soil mixture as an anaerobic process and rock layers as an aerobic process are needed in the action mechanism of MSL and have their respective functions. The aerobic zone functions to decompose organic material, oxidize ferrous ions to ferric ions, phosphate binding, and nitrification. In the anaerobic zone, a denitrification process occurs (Adinda et al., 2015).

\section{Research method}

This research includes general preparation, toolmaking, tool testing, tool redesign, tool application, and evaluation. The materials used include Andisol soil, Zeolite, iron sand, ravel (1-3 $\mathrm{cm}$ ), and activated charcoal. Modeling the treatment unit, installing the wastewater treatment unit with the MSL system at the domestic waste source, and finishing. Modeling the treatment unit included mixing the soil composition in the anaerobic segment (Andisol soil, activated charcoal, and iron sand), arranging the layer components, and placing the wastewater inlet pipe, aeration pipe, and the unit outlet pipe. The treatment unit installation included the installation of the processing unit model in household domestic wastewater source pipes. The reactor dimensions were $60 \times 40 \times 100 \mathrm{~cm}$ with the main material of glass with a thickness of $5 \mathrm{~mm}$. The reactor was operated using a continue system. Finishing was tidying and beautifying the appearance of the units that have been installed. The Multi Soil Layer system design is shown in Figure 1.

Wastewater samples came from canteen waste around the Engineering Faculty of Diponegoro University. Sample testing was carried out by distributing domestic wastewater to a treatment unit that has been installed and measuring the quality of the COD parameters using SNI standards. Measurement of pH (SNI 06-6989.11-2004) and COD using a UV-Vis spectrophotometer (Genesys 10s, Thermo Fisher Scientific). 


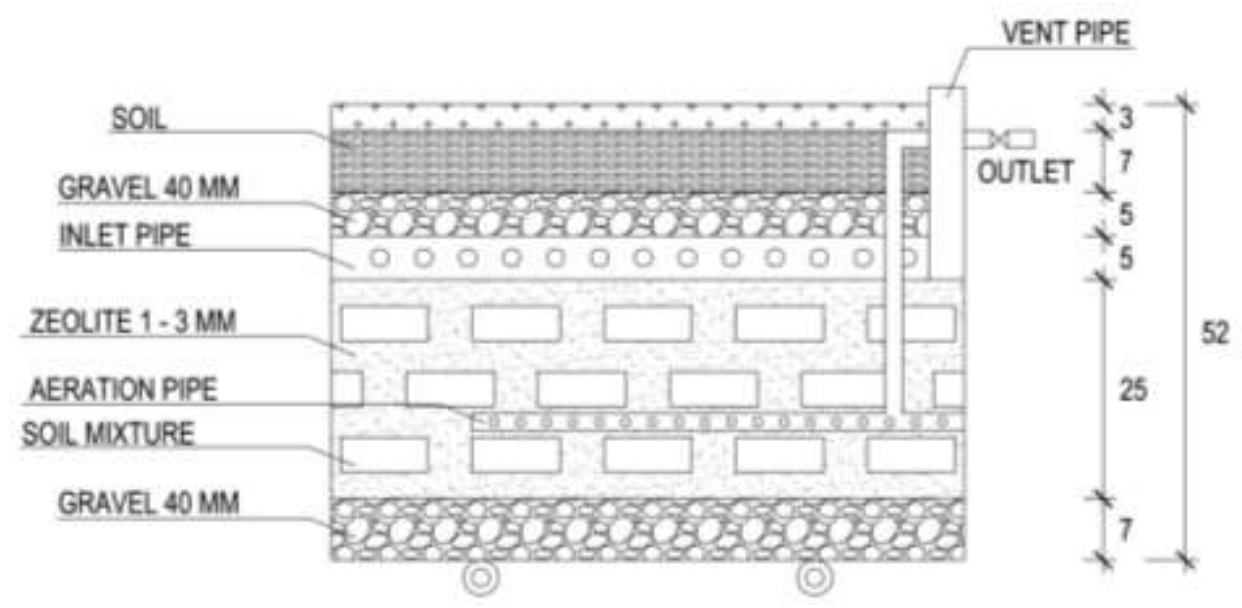

Figure 1. Multi Layer Soil system

\section{Result}

\subsection{Seeding and acclimatization}

Acclimatization aims to adapt microorganisms that have grown to be ready to treat wastewater. During the seeding and acclimatization process, the $\mathrm{pH}$ value of greywater must be ensured to be in the range of 6.5 - 7.5 (Leverenz et al., 2009). During the seeding and acclimatization process, the measurements of $\mathrm{pH}$, temperature, COD influent concentration on day 0 , and effluent COD concentration every three days were done. The percentage of COD removal at the acclimatization stage is shown in Figure 2.

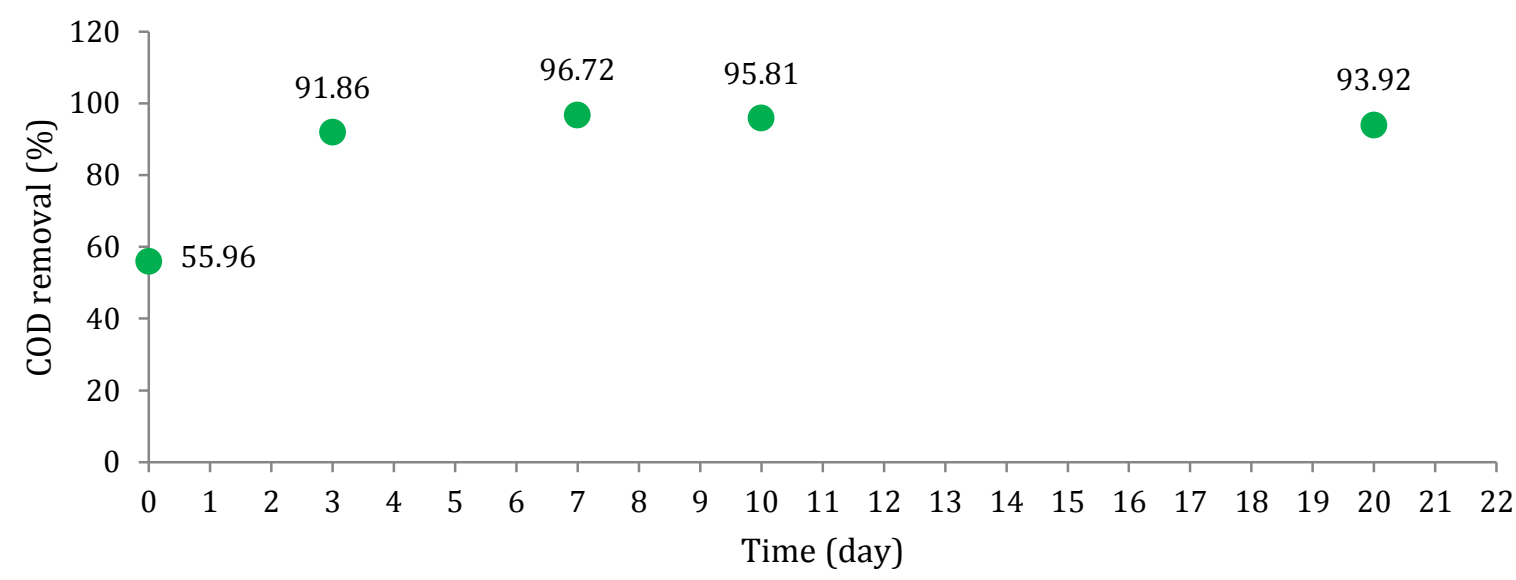

Figure 2. Graph of COD Removal Efficiency During Acclimatization

Based on Figure 2, it can be seen that the efficiency of COD removal on day 1 to day 7 tends to increase to $91.86 \%$, this indicates that the initial adhesion process of the biofilm starts. The percentage of COD removal is quite stable from day 7 to day 20 reaching $93.92 \%$. The removal 
efficiency which is starting to stabilize indicates that the formation of biofilms is in the maturase phase, meaning the reactor reaches a steady state. Gerardi (2006) states that in the early days of acclimatization, the efficiency of COD removal is still very low because biological processes are not yet operational. Physically, biofilm appears on the side of the reactor. Biofilm should be formed first at the top considering the waste flow in this study is down-flow which is influenced by gravity. The thicker biofilm on the side of the soil mixture block is suspected because it is not eroded by the flow of greywater from above, but it still gets a supply of nutrients from the flowing greywater. Another reason is the growth of biofilms in the phase of dispersion where some bacteria spread and colonize elsewhere (Rusmaputri, 2018). In addition to the surface of soil mixture blocks, biofilms are also found on rock surfaces, both broken stones, and zeolites. The existence of a thin layer of biofilm on the surface of broken rock and zeolites is characterized by the slippery surface of the rock when it is held (slimy).

PH measurements were carried out on MSL rhizome effluents. The results of $\mathrm{pH}$ measurements during the acclimation process are shown in Figure 3. Based on Figure 3 it can be seen that the initial $\mathrm{pH}$ of 5.2 means acid. The $\mathrm{pH}$ value of the effluent increases on the 3rd, 4th, 5th, and 7th day measurements to reach 6.9. This increase is due to the oxidation of organic matter aerobically and the respiration of microorganisms that produce NH3. NH3 is generally alkaline. Based on the COD parameters, the reactor reaches a steady state (steady) on the 20th day, the $\mathrm{pH}$ of the effluent on that day is 7.0. This $\mathrm{pH}$ value is in accordance with the range so that bacteria can live which is 6-9 (Zahara, 2014). According to Leverenz et al. (2009) the optimum pH required in the process of degradation by bacteria is between $6.5-7.5$.

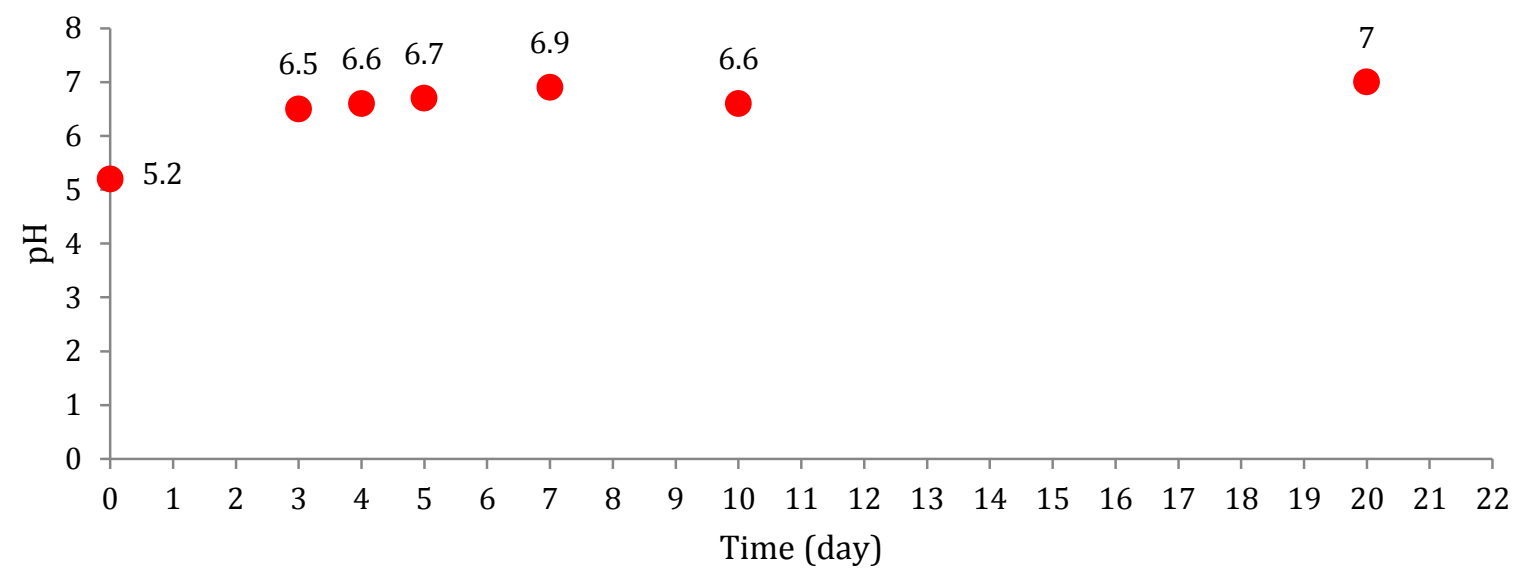

Figure 3. Graph of $\mathrm{pH}$ values during acclimatization

As with pH measurements, temperature measurements are also carried out on the effluent. Daily temperature data during the acclimation process is presented in Figure 4. Based on Figure 4 above, it can be seen that the temperature of all reactors is still in the range of $27^{\circ} \mathrm{C}-31.6^{\circ} \mathrm{C}$. This value is in accordance with Semarang City temperature data at the time of the study, which was between $26^{\circ} \mathrm{C}-34^{\circ} \mathrm{C}$. 


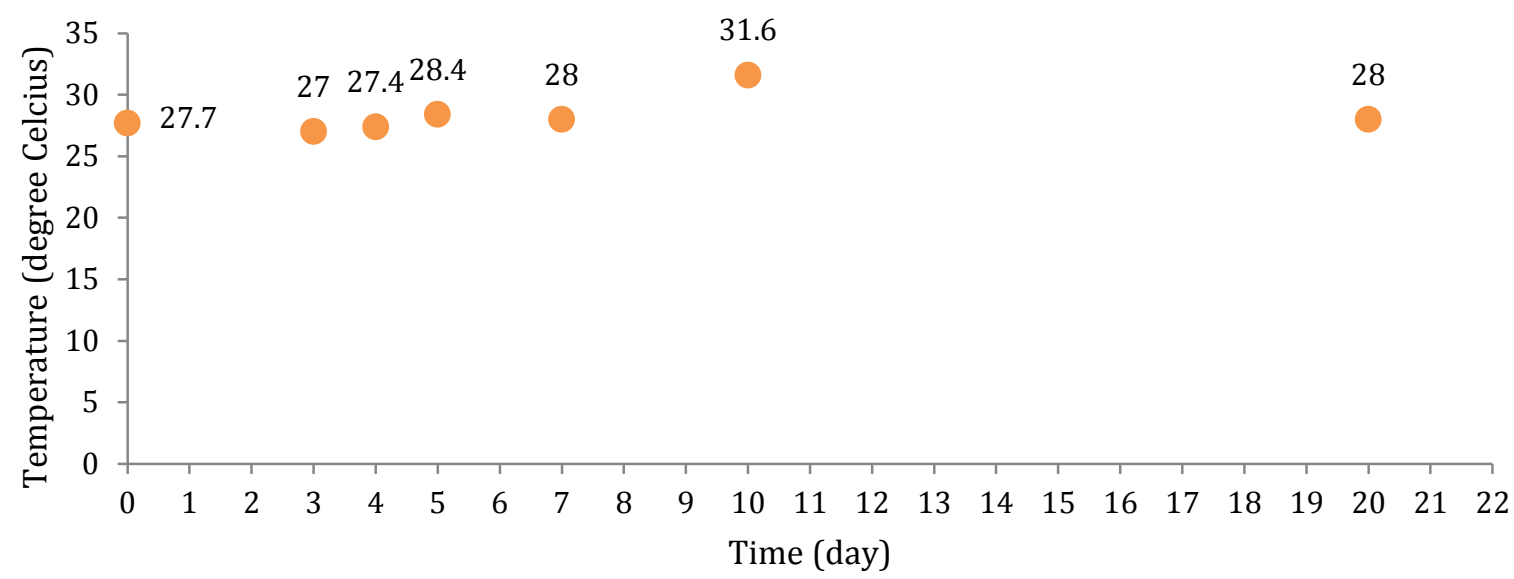

Figure 4. Temperature Graph During Acclimatization

\subsection{The efficiency of the MSL system in removing COD and BOD concentrations}

After the seeding and acclimatization process is completed, it then proceeds with running. In the running stage, the reactor is run intermittently, by flowing waste every hour from 6 a.m. to 5 p.m. The reactor is run intermittently on the grounds that there is no equalization tub before the greywater enters the MSL reactor so that the organic discharge and load are not uniform. This condition is not appropriate for continuous drainage. In addition, continuous drainage with small discharges is difficult given the Hydraulic Retention Time (HRT) chosen is 24 hours. The reactor is run intermittently also to equate the conditions in the field where greywater is not generated every hour but only at a certain time when humans generally carry out activities i.e. 6 a.m. to 5 p.m. Greywater produced at night and early morning is less when compared to greywater produced in the morning to evening.

Nadais et al. (2008) state that in reactors that are run intermittently there are feedless periods and1 sequential periods. In the sequential stage, the reactor content enters / discharges. While at the feedless stage, the reactor content does not occur/discharged. So in this study, the feedless period occurs from 6 p.m. to 5 a.m., while the sequential period occurs from 6 a.m. to 5 p.m.

The $\mathrm{pH}$ value of greywater influents used in this main study tends to be acidic. Supposedly, the pH of domestic waste tends to be near neutral (Doraja et al., 2012). This acidic nature can occur due to the presence of organic acid content in greywater samples. Greywater which is used as an influent is the previous day waste and is only tested \pm 12 hours after sampling from the source. In addition, greywater samples placed in jerrycan create anaerobic conditions. This condition triggers anaerobic bacteria to convert organic matter in the greywater sample to acid. The results of $\mathrm{pH}$, temperature, and COD measurements are shown in Table 2 .

The efficiency of COD removal in 24-hour HRT is able to set aside COD of $81.31 \%$. This result is better than Kusuma et al. (2013) research which results in a removal efficiency of $71.9 \%$. In that study, domestic waste was treated using wasps' biofilter media. The initial COD concentration was $4,221.67 \mathrm{mg} / \mathrm{L}$, after going through processing using MSL it dropped to 
$789.00 \mathrm{mg} / \mathrm{L}$. In this case, organic substances are degraded by microorganisms in biofilms. This means that the nutrients in greywater are still used by bacteria to grow. MSL technology is quite effective in removing greywater COD using 24-hour HRT.

Table 2. Results of measurements of $\mathrm{pH}$, temperature, and\% of COD removal in HRT 3, 6, 9, and 24 hours

\begin{tabular}{cccc}
\hline HRT (hour) & pH & Temperature & \% COD Removal \\
\hline & & HRT 24 hours & \\
0 & 6,43 & 31,4 & 0,00 \\
24 & 6,18 & 28,8 & 81,31 \\
& & HRT 3, 6, 9 hours & \\
0 & 7,60 & 27,8 & 0,00 \\
3 & 6,08 & 30,1 & 85,68 \\
6 & 6,06 & 30,4 & 86,85 \\
9 & 6,03 & 30,2 & 93,44 \\
\hline
\end{tabular}

When witnessing the conditions in the field, the waste disposal is carried out without knowing the time, meaning that at any time the community carries out MCK activities and others. Therefore, it is necessary to know the stability of MSL in setting aside COD pollutants. In this research, variations of 3,6 , and 9 hours HRT were performed. The results of the percentage of COD removal are shown in Figure 5.

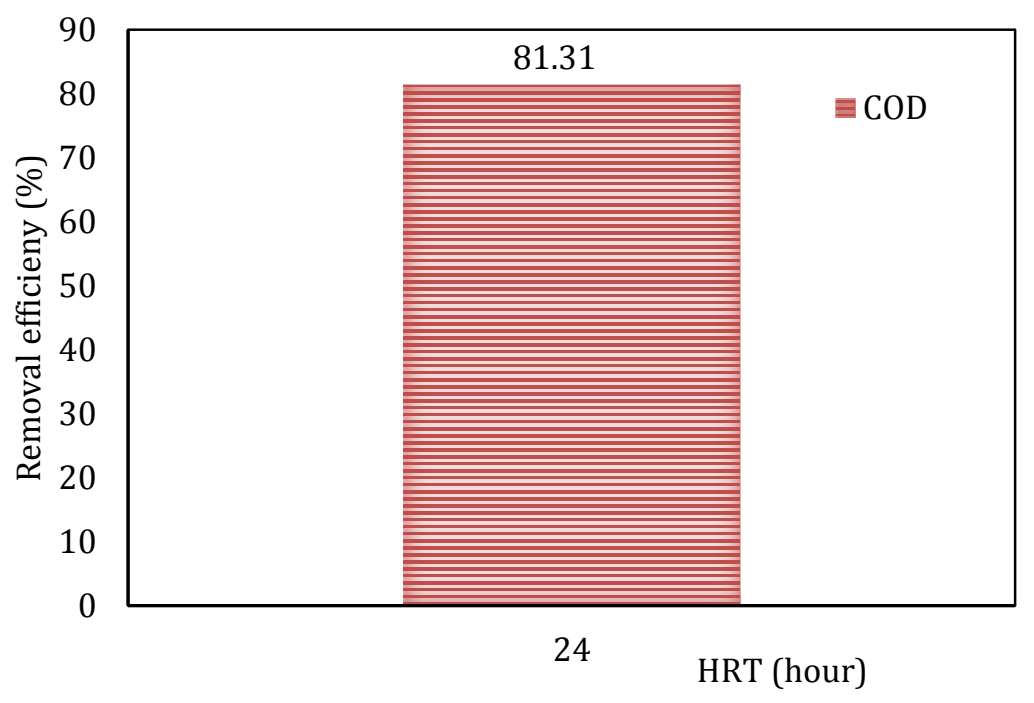

Figure 5. The results of the study the percentage of COD, BOD, fat oil removal on 24 hours HRT

Based on Figure 6 it appears that the percentage of COD removal is quite stable in the range of $85.68 \%$ to $93.44 \%$. This value is higher than 24 hours HRT. The possibility of a 24 -hour HRT that there is a pause a few days after the acclimatization process for the trial and error process so that the bacteria in the reactor readapts to both the flow of waste and the difference 
in COD concentrations every day. In 3, 6, 9 hours HRT, there is a possibility that biofilm can degrade organic matter well. However, effluent COD concentrations tend to be stable to 279.33 $\mathrm{mg} / \mathrm{L}$. This shows that the MSL reactor can only reduce COD to that value. This value still exceeds the domestic wastewater quality standards required in the Regulation of the Minister of Environment and Forestry of the Republic of Indonesia Number 68 of 2016 concerning Domestic Wastewater Quality Standards of $100 \mathrm{mg} / \mathrm{L}$.

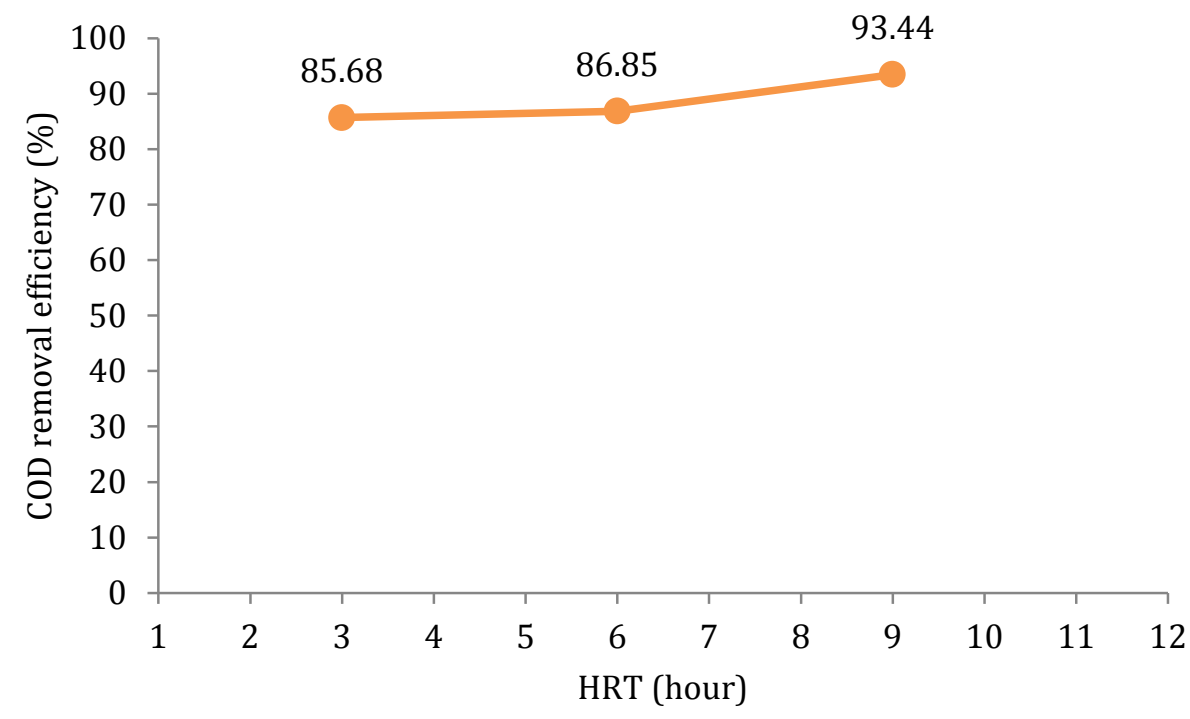

Figure 6. Results of the study on the percentage of fat COD removal in 3, 6, 9 hours HRT

\section{Conclusion}

MSL system is able to set aside COD well. The highest COD removal efficiency was $93.44 \%$ at 9-hour HRT. The percentage of pollutant removal as COD is quite stable but the effluent quality does not meet the quality standards required in 3,6, to 9 hours HRT. The effluent needs tertiary treatment so as not to pollute water bodies such as environmentally friendly wetlands.

\section{Acknowledgment}

Thanks to the Faculty of Engineering, Diponegoro University for funding this research through an innovative research scheme.

\section{References}

Adinda, T., Elystia, S., \& Hs, E. (2015). Metoda Multi Soil Layering dalam Pengolahan Air Gambut dengan Variasi Hydraulic Loading Rate dan Material Organik pada Lapisan Anaerob. Jurnal Online Mahasiswa Fakultas Teknik Universitas Riau, 2(1), 1-7.

Chen, X., Luo, A. C., Sato, K., Wakatsuki, T., \& Masunaga, T. (2009). An Introduction of a Multi-SoilLayering System: a Novel Green Technology for Wastewater Treatment in Rural Areas. Water and Environment Journal, 23(4), 255-262. 
Doraja, P. H., Shovitri, M., \& Kuswytasari, N. D. (2012). Biodegradasi limbah domestik dengan menggunakan inokulum alami dari tangki septik. Jurnal Sains Dan Seni ITS, 1(1), E44-E47.

Elystia, S., Indah, S., \& Helard, D. (2012). Efisiensi Metode Multi Soil Layering (MSL) dalam Penyisihan COD dari Limbah Cair Hotel (Studi Kasus: Hotel“ X" Padang). Jurnal Teknik Lingkungan UNAND, 9(2), 121-128.

Gerardi, M. H. (2006). Wastewater Bacteria. New Jersey: John Wiley \& Sons, Inc.

Kusuma, B. A., Sutrisno, E., \& Sumiyati, S. (2013). Penurunan Kadar Bod Dan Amonia Pada Air Limbah Domestik mengunakan Teknologi Biofilm Dengan Media Filter Bunga Pinus, Potongan Bambu, Dan Bioball. Jurnal Teknik Lingkungan, 2(4), 1-6.

Latrach, L., Ouazzani, N., Hejjaj, A., Mahi, M., Masunaga, T., \& Mandi, L. (2018). Two-stage vertical flow multi-soil-layering (MSL) technology for efficient removal of coliforms and human pathogens from domestic wastewater in rural areas under arid climate. International Journal of Hygiene and Environmental Health, 221(1), 64-80.

Leverenz, H. L., Tchobanoglous, G., \& Darby, J. L. (2009). Clogging in intermittently dosed sand filters used for wastewater treatment. Water Research, 43(3), 695-705.

Masi, F., \& Martinuzzi, N. (2007). Constructed wetlands for the Mediterranean countries: hybrid systems for water reuse and sustainable sanitation. Desalination, 215(1-3), 44-55.

Masunaga, T., Sato, K., Mori, J., Shirahama, M., Kudo, H., \& Wakatsuki, T. (2007). Characteristic of Waswater Treatment Using a Multi-soil-Layering System in Relation to Waswater Contaminan Levels and Hydraulic Loading Rate. Soil Science and Plat Nutrition, 53(2), 215223.

MLHK-RI. Peraturan Menteri Lingkungan Hidup dan Kehutanan Republik Indonesia Nomor P.68/Melhk/Sekjen/Kum.1/8/2016 tentang Baku Mutu Air Limbah Domestik (2016). Indonesia.

Mutia, R., Elystia, S., \& Yenie, E. (2015). Metode Multiv Soil Layering dalam Penyisihan Parameter TSS Limbah Cair Kelapa Sawit dengan Variasi Hydraulic Loading Rate (HLR) dan Material Organik pada Lapisan Anaerob. Jurnal Online Mahasiswa Fakultas Teknik Universitas Riau, 2(1-6).

Nadais, H., Barbosa, M., Almeida, A., Cunha, A., Capela, I., \& Arroja, L. (2008). Intermittent operation of UASB reactors as a strategy to enhance anaerobic degradation of dairy wastewaters. In Proceedings of the 5 th Conference on Environment, Ecosystems and Development (EED'08) (pp. 38-43). Cairo.

Rusmaputri, F. (2018). Daya Hambat Ekstrak Buah Delima Merah (Punica granatum Linn) Terhadap Pertumbuhan Streptococcus sanguis. Universitas Jember.

Santoso, S. (2014). Limbah cair domestik: Permasalahan dan dampaknya terhadap lingkungan. Banyumas: Fakultas Biologi UNSOED.

Suoth, A. E., \& Nazir, E. (2016). Karakteristik Air Limbah Rumah Tangga Pada Salah Satu Perumahan Menengah Keatas di Tangerang Selatan. ECOLAB, 10(2), 80-88.

Sy, S., \& Sofyan. (2011). Aplikasi Metoda MSL (Multi Soil Lareying) untuk Mengolah Air Limbah Industri Edilble Oil. Jurnal Riset Industri, 5(3), 227-238. 
Wakatsuki, T., Esumi, H., \& Omura, S. (1993). High performance and N \& P-removable on-site domestic waste water treatment system by multi-soil-layering method. Water Science and Technology1,27(1), 31-40.

Zahara, I. (2014). Pengaruh Pengadukan terhadap Produksi Biogas pada Proses Metanogenesis Berbahan Baku Limbah Cair Pabrik Kelapa Sawit. Universitas Sumatera Utara. 